\title{
Effect of Oral Administration of Gnidia Stenophylla Gilg Aqueous Root Extract on Food Intake and Histology of Gastrointestinal Tract in Mice
}

\author{
Tilahun Alemayehu Nigatu ${ }^{1 *}$, Mekbeb Afework ${ }^{2}$, Kelbessa Urga ${ }^{3}$, Wondwossen \\ Ergete $^{4}$, Tewodros Gebremariam Gebretsadik ${ }^{1}$, Eyasu Makonnen ${ }^{5}$
}

OPEN ACCESS

Citation: Tilahun Alemayehu Nigatu, Mekbeb Afework, Kelbessa Urga, Wondwossen Ergete, Tewodros Gebremariam Gebretsadik, Eyasu Makonnen. Effect of Oral Administration of Gnidia Stenophylla Gilg Aqueous Root Extract on Food Intake and Histology of Gastrointestinal Tract in Mice. Ethiop J Health Sci 2017;27(1):35-46. doi: http://dx.doi.org/10.4314/ejhs.v27i1.6

Received: July 16, 2016

Accepted: November 6, 2016

Published: January 1, 2017

Copyright: Tilahun AN, et al. This is an open access article distributed under the terms of the Creative Commons Attribution License, which permits unrestricted use, distribution, and reproduction in any medium, provided the original author and source are credited. Funding: Nil

Competing Interests: The authors declare that this manuscript was approved by all authors in its form and that no competing interest exists.

Affiliation and Correspondence: ${ }^{1}$ Department of Biomedical Sciences, College of Health Sciences, Jimma University, Jimma, Ethiopia

${ }^{2}$ Department of Anatomy, School of Medicine, College of Health Sciences, Addis Ababa University, Ethiopia ${ }^{3}$ Ethiopian Public Health Institute, Traditional and Modern Medicine, Vaccines Directorate, Ethiopia ${ }^{4}$ Department of Pathology, School of Medicine, College of Health Sciences, Addis Ababa University, Ethiopia ${ }^{5}$ Department of Pharmacology, School of Medicine, College of Health Sciences, Addis Ababa University, Ethiopia

*Email: tilalemnig2012@gmail.com

\section{ABSTRACT}

BACKGROUND: Aqueous preparations of a medicinal plant, Gnidia stenophylla Gilg (Thymelaeaceae) are commonly used to cure malaria and other ailments in Ethiopia. This study evaluated the safety of the plant extract by determining its effects on food intake and histology of gastrointestinal tract (GIT) after oral administration for 13 weeks in albino mice.

METHODS: Thirty mice were equally assigned to three groups. Group I served as control and received a vehicle while groups II and III were given 400 and $800 \mathrm{mg} / \mathrm{kg}$ body weight/day plant extract respectively, orally, for 13 weeks. At the end of the study, the mice were scarified and postmortem gross and histopathological evaluations were performed on their stomachs and intestines.

RESULTS: Chronic oral treatment with the extract for 13 weeks did not induce any sign of illness and death and had no effect on food intake of the mice. Furthermore, extract treatment at both doses did not produce any detectable gross morphological change in GIT. Microscopic evaluation of sections of the stomach, duodenum and jejunum of the mice treated with $400 \mathrm{mg} / \mathrm{kg}$ body weight did not show any histopathological change. In the mice treated with $800 \mathrm{mg} / \mathrm{kg}$ body weight, however, the GIT sections revealed cytoplasmic vacuolation, hydropic degeneration and excessive erosion of the surface mucosal cells.

CONCLUSION: The results of this study revealed that aqueous root extract of $G$. stenophylla at effective antimalarial dose is safe even when taken for a longer period in mice. At a higher dose, however, the extract may induce gastrointestinal irritation. Further studies on other vital organs and non-rodent species including humans are recommended.

KEYWORDS: Gnidia stenophylla Gilg, aqueous root extract, chronic toxicity, histology, histopathology, gastrointestinal tract, gastrointestinal irritation deficit, Ethiopia 


\section{INTRODUCTION}

Traditional medicine is an ancient medical practice, but is still widely used in the prevention and treatment of various health problems worldwide, including Ethiopia (1-10). Although many health problems have been treated using medicinal plants, acute and chronic phytotoxic effects of some plants are also reported (11-13). Gnidia stenophylla Gilg (GSG), usually known by its vernacular name "Kataricha" in Afan Oromo, is one of the medicinal plants traditionally used in Ethiopia (14-15). The plant is a woody-based perennial herb (about 20-60 cm high) in the family Thymelaeaceae, which grows naturally in Ethiopia and in other tropical and sub-tropical African countries (16-17).

The medicinal value of Gnidia species is attributed mainly to their roots (18-19). In rural Ethiopia, aqueous preparations of the plant roots are used for treating malaria and its associated symptoms (18). The root decoction is also employed as traditional remedy for gonorrhea, syphilis, leprosy, ascaris, rabies, heart pain and rheumatic pain (20-22). Moreover, the root powder is pasted with honey and employed as a remedy for breast cancer and/or tumors. Unfortunately, the scientific data to support these claims are still scarce.

Root extracts of Gnidia species are known to contain chemical constituents such as diterpenes (gnidicin, gnididin and gniditrin), daphnetin, daphnenin and coumarin, which are thought to account for many of their presumed therapeutic effects $(19,22)$. Flavonol glycosides including kaempferol-3-O-glucoside, yuankanin and manniflavanone are also isolated from the methanol extract of the aerial parts of $G$. involucrata (23). A recent report by Mohammed et.al (24) described phenols, flavonoids, steroids, tannins and saponins as the main phytochemical constituents of the aqueous root extract of $G$. stenophylla.

Recently, the traditional claim of the Gnidia species for treatment of malaria has been confirmed by pharmacological studies (18). However, scientific evidence on their safety is scarce, and only a few studies have investigated their potential toxicity (25). Among the Gnidia species, G. involucrata and G. latifolia are known to cause enteritis, nephritis, cardiomyopathy and blistering of skin in humans (19). General atrophy of the body fat and accumulation of excess fluid in the body cavities, as well as lymphocytopaenia and lymphocytic degeneration in lymph nodes and spleen are also reported (26). Documentation on the poisonous plants of Ethiopia has shown that some Gnidia species are generally poisonous to humans and animals (25). Nevertheless, there is no scientific report on the potential toxicity of using G. stenophylla as herbal remedy. This study was therefore aimed at assessing the toxicity of aqueous root extract of $G$. stenophylla by determining its effects on food intake and histology of gastrointestinal tract (GIT) after chronic oral administration for 13 weeks in mice.

\section{MATERIALS AND METHODS}

Plant material collection and extraction: The underground roots of GSG were freshly collected from Bale, Dello Menna area, near Melka-Cira River about $550 \mathrm{~km}$ Southeast of Addis Ababa in August 2009. A taxonomist confirmed the identity of the plant, and a voucher specimen (No. 0012009) of the entire plant was deposited at the herbarium of the Traditional and Modern Medicine, Drug Research Directorate (TMMDRD) of the Ethiopian Public Health Institute (EPHI), Addis Ababa. Ethnomedical information about the plant was obtained from literature survey (18) and oral interviews with traditional healers. The collected fresh roots were dried, cut into pieces and ground to fine powder. Two hundred grams of the powdered material of the plant was cold macerated with $1000 \mathrm{ml}$ of distilled water at room temperature and agitated overnight. The mixture was filtered and freeze-dried at $5000 \mathrm{mbr}$ and $57^{\circ} \mathrm{c}$ using a lyophilizer (Labconco, Inc, USA), yielding a dark-brown amorphous crude extract. The extract was then kept in sealed plastic vials and stored in desiccators at room temperature until used.

Experimental animals preparation: A total of thirty adult male and female Swiss albino mice (Mus musculus), 6-7 weeks old and weighing 20$25 \mathrm{~g}$, were used in this study. The animals were housed in several groups in rectangular polyacrylic cages with dust-free paddy husk as

DOI: http://dx.doi.org/10.4314/ejhs.v27i1.6 
bedding material. Throughout the study period, the male and female mice were kept in separate cages to avoid breeding, and maintained under constant laboratory conditions of temperature $\left(22 \pm 2^{\circ} \mathrm{c}\right)$ with $12 \mathrm{hrs}$ light/dark cycle. All animals were allowed free access to standard pellet diet and clean tap water ad libitum except when starvation was otherwise needed. The food and water were changed, daily and the cages were cleaned and the husk changed every three days. All mice were apparently healthy, and an acclimatization period of 7 days was allowed before experimentation in order to minimize any non-specific stress (27-29).

Selection of test doses and dosing times: Repeated dose (sub-chronic) toxicity study was conducted to investigate the safety of the aqueous root extract of G. stenophylla by determining its toxic effects on general health, body weight, food intake and histology of gastrointestinal tract after oral administration of the extract for 13 weeks in mice. At the commencement of the study, thirty mice were randomly assigned to three groups (IIII) of ten animals, five males and five females each. Group I served as a control and received 5 $\mathrm{ml}(0.5 \mathrm{ml} / \mathrm{mouse})$ distilled water orally, once a day at $24 \mathrm{hrs}$ intervals, throughout the study period. Groups II and III were orally administered to single daily doses of 400 and $800 \mathrm{mg} / \mathrm{kg}$ body weight/day of the extract respectively in $0.5 \mathrm{ml}$ distilled water for 13 weeks. The tested doses were selected based on various literatures (21-23), which reported $400 \mathrm{mg} / \mathrm{kg}$ of aqueous extract of G. stenophylla as effective dose for in-vivo antiplasmodial activity. The extract was freshly dissolved in $5 \mathrm{ml}(0.5 \mathrm{ml} / \mathrm{mouse})$ distilled water immediately before administration. Both the extract and the vehicle were administered orally, in a way used by the traditional healers, using a bucco-gastric cannula mounted on a $5 \mathrm{ml}$ syringe. During the whole period of the study, the animals in all groups were regularly monitored for any behavioral changes and clinical symptoms of toxicity such as vomiting, diarrhea, ataxia, illness and death. As suggested by WHO (30), body weight of all mice and food intake of each group were measured before the start of drug administration, once a week throughout the study period, and at the end of the experiment using a semi-microbalance sensitive to $0.001 \mathrm{~g}$. The body weight taken at the beginning of the experiment (on day 1) immediately before the first administration was considered to be initial weight, while the weight taken at the end of the experiment (on day 95) immediately after the last administration was considered final body weight. For each group, the food consumption was expressed in grams per kg body weight per day. Similarly, mean body weights were calculated and used for analysis of body weight progress.

Tissue specimen collection: At the end of the 13 weeks experiment, the mice in each group were anaesthetized under diethyl ether and sacrificed by cervical dislocation. At autopsy, the stomach and the small and large intestines were visually examined for any signs of gross lesions. The stomach and portions of the small and large intestines were removed from each animal and rinsed under stream of water. The stomach was then opened along the greater curvature and observed for any gross lesion according to the method described by Nwinyi et al. (32). Similarly, the intestines were opened longitudinally and visually examined. The organs from the groups given the plant extract were compared blindly with those of the controls. Thereafter, small tissue samples were randomly dissected out transversely from the body region of the stomach, duodenum jejunum and placed in fixative for histopathological examination.

$\begin{aligned} & \text { Tissue processing, staining and } \\ & \text { histopathological evaluations: }\end{aligned}$
For
histopathological studies, each of the tissue samples taken from the stomach, duodenum and jejunum were immersion-fixed separately in $10 \%$ neutral buffered formalin at room temperature. Following fixation, the tissues were rinsed in running water, dehydrated by immersing in ascending grades of ethyl alcohol, cleared in two changes of absolute xylene and embedded in paraffin blocks. The tissue blocks were sectioned at 5-6 $\mu \mathrm{m}$, the sections deparaffinized by xylene and hydrated with ethanol, stained regressively with Harris' hematoxylin for 10 minutes, washed in tap water and dipped into $1 \%$ acid alcohol for differentiation and to remove excess stain. The tissue sections were counterstained in $1 \%$ alcoholic eosin for 1 minute, dehydrated in

DOI: http://dx.doi.org/10.4314/ejhs.v27i1.6 
increasing concentrations of ethanol, cleared in xylene and mounted on cover slips. The prepared microscopic slides were examined carefully under light microscope. Tissue sections from the treated groups were evaluated for any evidence of histopathological changes with respect to those of the controls. Photomicrographs of selected slides were taken using digital photo camera mounted on a binocular compound microscope.

Statistical analysis: Numerical data obtained from the experiments were analyzed statistically on SPSS version 19.0. Data for body weight and food intake were presented as mean \pm standard error of mean (SEM). Differences between the treated and control groups were compared using one-way analysis of variance (ANOVA), followed by Dunnett's t-test to determine their level of significance. Tukey's post-hoc multiple range test was also employed to compare between the treated groups. Differences between the various groups were considered statistically significant at $\mathrm{P}<0.05$.

Ethical Clearance: The study protocol was approved by the institutional review board of the School of Medicine, Addis Ababa University, (protocol number: 043/08/Anat). In addition, written permission was obtained from the Drug Research Directorate of the Ethiopian Public Health Institute (EPHI), Addis Ababa. All toxicity studies involving the experimental animals were conducted in compliance with the general guidelines for methodologies on research and evaluation of traditional medicine as promulgated by WHO (30). The research report was prepared in line with all the recommendations provided in the Animal Research: Reporting of In Vivo Experiments (ARRIVE) guidelines published online in PLOS Biology (31).

\section{RESULTS}

Effects of $G$. stenophylla Gilg aqueous root extract on general health and food intake of mice: Cage side observations of the animals after administration of both the vehicle and the extract at 400 and $800 \mathrm{mg} / \mathrm{kg}$ body weight were carried out daily for general signs of abnormalities throughout the study period. All animals in the treated and control groups appeared normal and did not show any extract-related clinical signs and symptoms of toxicity throughout the study period. No animals were found dead, and all of them survived until the scheduled necropsy. The effect of G. stenophylla Gilg root extract on the body weight of male and female mice during the 13 weeks of chronic treatment is shown in Table 1.

Table 1: Effect of G. stenophylla Gilg root extract on the body weight $(\mathrm{g})$ of male and female mice as compared to the controls.

\begin{tabular}{lllcc}
\hline & & \multicolumn{2}{c}{ Treatment Groups(mg/kg body weight/day) } \\
\hline \multirow{2}{*}{ Initial bw } & Male & Control & $\mathbf{4 0 0}$ & $\mathbf{8 0 0}$ \\
& Female & $24.00 \pm 0.63$ & $24.80 \pm 0.73(0.610)$ & $25.40 \pm 0.60(0.265)$ \\
Week 2 & Male & $28.60 \pm 1.21$ & $24.40 \pm 0.93(0.985)$ & $24.40 \pm 0.81(0.985)$ \\
& Female & $29.00 \pm 0.41$ & $28.50 \pm 1.76(0.299)$ & $28.40 \pm 0.75(0.949)$ \\
Week 4 & Male & $29.25 \pm 0.48$ & $30.50 \pm 0.29(0.365)$ & $27.67 \pm 1.33(0.700)$ \\
& Female & $33.00 \pm 1.73$ & $28.75 \pm 0.85(0.111)$ & $32.60 \pm 0.87 * *(0.008)$ \\
Week 6 & Male & $30.75 \pm 0.48$ & $31.00 \pm 0.58(0.973)$ & $34.75 \pm 1.38 *(0.022)$ \\
& Female & $33.33 \pm 0.88$ & $31.00 \pm 0.53(0.751)$ & $32.67 \pm 1.20(0.249)$ \\
Week 8 & Male & $30.50 \pm 0.50$ & $30.67 \pm 0.67(0.994)$ & $34.75 \pm 1.38(0.092)$ \\
& Female & $35.00 \pm 058$ & $33.75 \pm 0.95(0.875)$ & $33.00 \pm 2.00(0.706)$ \\
Week 10 & Male & $32.00 \pm 1.00$ & $35.33 \pm 0.88(0.114)$ & $39.00 \pm 1.00 * *(0.008)$ \\
& Female & $36.00 \pm 0.58$ & $33.33 \pm 0.33(0.490)$ & $32.33 \pm 1.45(0.147)$ \\
Week 12 & Male & $36.00 \pm 1.00$ & $37.00 \pm 0.58(0.908)$ & $36.03 \pm 2.14(1.00)$ \\
& Female & $39.00 \pm 0.58$ & $36.67 \pm 0.88(0.054)$ & $35.33 \pm 2.40(0.488)$ \\
& Male & $39.00 \pm 1.00$ & $35.80 \pm 0.79(0.507)$ & $36.05 \pm 2.33(0.523)$ \\
& Female & $37.83 \pm 0.87$ & $36.40 \pm 0.61(0.228)$ & $35.93 \pm 2.40(0.557)$ \\
\hline
\end{tabular}

DOI: http://dx.doi.org/10.4314/ejhs.v27i1.6 
Values are given as Mean \pm S.E.M for each male and female subgroup. $\mathrm{N}=10$. The figures under brackets indicate the calculated $\mathrm{p}$ values of the treatment group as compared to the control;*= significant $(\mathrm{p}<0.05) ; * *=$ highly significant $(\mathrm{P}<0.01)$. The mean difference is considered significant at 0.05 ; bw $=$ body weight

As shown, the extract did not have any significant effect on body growth patterns of the mice. Body weight of both treated and control groups increased progressively as the duration increased, and no significant difference was observed in the mean values of the body weights of mice treated with $400 \mathrm{mg} / \mathrm{kg}$ in both sexes and the female mice treated with $800 \mathrm{mg} / \mathrm{kg}$. However, a significant increase was observed in the mean values of the body weights of male mice treated with $800 \mathrm{mg} / \mathrm{kg}$ during the fourth $(\mathrm{p}<0.01)$, sixth $(\mathrm{P}<0.05)$ and tenth $(\mathrm{P}<0.01)$ weeks compared with the control
(Table 1). However, there was no significant difference in the final body weight between the control and extract treated groups in both sexes.

Regarding the food consumption, there was no significant difference between the extract treated and control groups throughout the study period, except during the second week in which the male mice treated with $400 \mathrm{mg} / \mathrm{kg}$ consumed more food than the control (Table 2). In each group, the male mice tended to consume more food than their female counterparts.

Table 2: Effect of G. stenophylla root extract on food intake (in $\mathrm{g} / \mathrm{kg}$ body weight per day) of male and female mice as compared to the controls.

\begin{tabular}{llccc}
\hline & & & \multicolumn{2}{c}{ Treatment Groups $(\mathrm{mg} / \mathrm{kg}$ body weight/day $)$} \\
\hline Initial FI & Male & $760.50 \pm 5.50$ & 600 & 800 \\
& Female & $524.25 \pm 5.00$ & $566.00 \pm 5.00(0.123)$ & $584.00 \pm 6.00(0.284)$ \\
& Male & $587.50 \pm 8.50$ & $797.00 \pm 33.00(0.017)^{*}$ & $670.50 \pm 45.50(0.237)$ \\
Week 2 & Female & $497.50 \pm 7.50$ & $581.50 \pm 15.50(0.837)$ & $656.50 \pm 199.50(0.582)$ \\
& Male & $705.50 \pm 3.50$ & $901.50 \pm 221.50(0.574)$ & $683.00 \pm 100.00(0.991)$ \\
Week 4 & Female & $374.00 \pm 20.00$ & $632.50 \pm 124.50(0.171)$ & $680.00 \pm 59.00(0.120)$ \\
& Male & $639.50 \pm 277.50$ & $818.50 \pm 329.50(0.873)$ & $728.50 \pm 239.50(0.965)$ \\
Week 6 & Female & $361.50 \pm 71.50$ & $474.00 \pm 156.00(0.675)$ & $505.00 \pm 5.00(0.556)$ \\
& Male & $803.50 \pm 392.50$ & $744.50 \pm 239.50(0.984)$ & $623.00 \pm 162.00(0.868)$ \\
Week 8 & Female & $534.50 \pm 67.50$ & $815.00 \pm 171.00(0.255)$ & $561.00 \pm 31.00(0.978)$ \\
Week 10 & Male & $765.50 \pm 47.50$ & $736.50 \pm 94.50(0.944)$ & $640.50 \pm 67.50(0.463)$ \\
& Female & $315.00 \pm 46.00$ & $433.50 \pm 33.50(0.136)$ & $490.50 \pm 5.00(0.054)$ \\
Week 12 & Male & $603.33 \pm 50.52$ & $665.25 \pm 41.07(0.668)$ & $596.25 \pm 67.70(0.994)$ \\
& Female & $328.67 \pm 115.52$ & $560.25 \pm 48.67(0.083)$ & $505.25 \pm 47.96(0.188)$ \\
Week 13 & Male & $605.35 \pm 67.45$ & $670.4 \pm 79.57(0.456)$ & $600.8 \pm 98.16(0.456)$ \\
& Female & $489.5 \pm 89.32$ & $570.4 \pm 55.61(0.154)$ & $511.7 \pm 28.32(0.243)$ \\
\hline
\end{tabular}

Values are given as Mean \pm S.E.M, $\mathrm{N}=10$. The figures under brackets indicate the calculated $\mathrm{p}$ values of the treatment group as compared to the control. *The mean difference is considered significant at $\mathrm{P}<0.05 ; \mathrm{FI}=$ food intake.

Effect of oral administration of h G. stenophylla Gilg root extract on gross macroscopic appearance and histology of the GIT: Postmortem macroscopic examination of all the studied internal organs, namely, stomach, small intestine and large intestine for any possible changes in positions, shapes, sizes and colors did not reveal any detectable gross abnormality. Light microscopic examination of the stomach, duodenum and jejunum sections of the different groups (both treated and controls) showed intact histological layers: mucosa, submucosa, muscularis externa and serosa.

The histology of stomach from mice treated with $400 \mathrm{mg} / \mathrm{kg}$ (Figure 1A) was comparable to that of the controls (Figure 1D) showing normal features: composed of entirely glandular mucosa supported by muscularis mucosa, relatively loose

DOI: http://dx.doi.org/10.4314/ejhs.v27i1.6 
submucosa and the muscularis externa. The gastric glands also contain the usual mucussecreting surface cells, acid-secreting parietal cells and pepsin-secreting peptic or chief cells. The parietal cells are characterized by large round shape with extensive eosinophilic (oxyntic) cytoplasm and centrally located nucleus. The chief cells, on the other hand, are recognized by their basally located nuclei and strongly basophilic granular cytoplasm (Figure 1A and D). However, the stomach sections of the mice treated with the oral dose of $800 \mathrm{mg} / \mathrm{kg}$ exhibited cytoplasmic vacuolation and hydropic degeneration in the surface mucosal cells (Figure 1B), while other cells were normal and similar with those of the controls (Figure 1C).
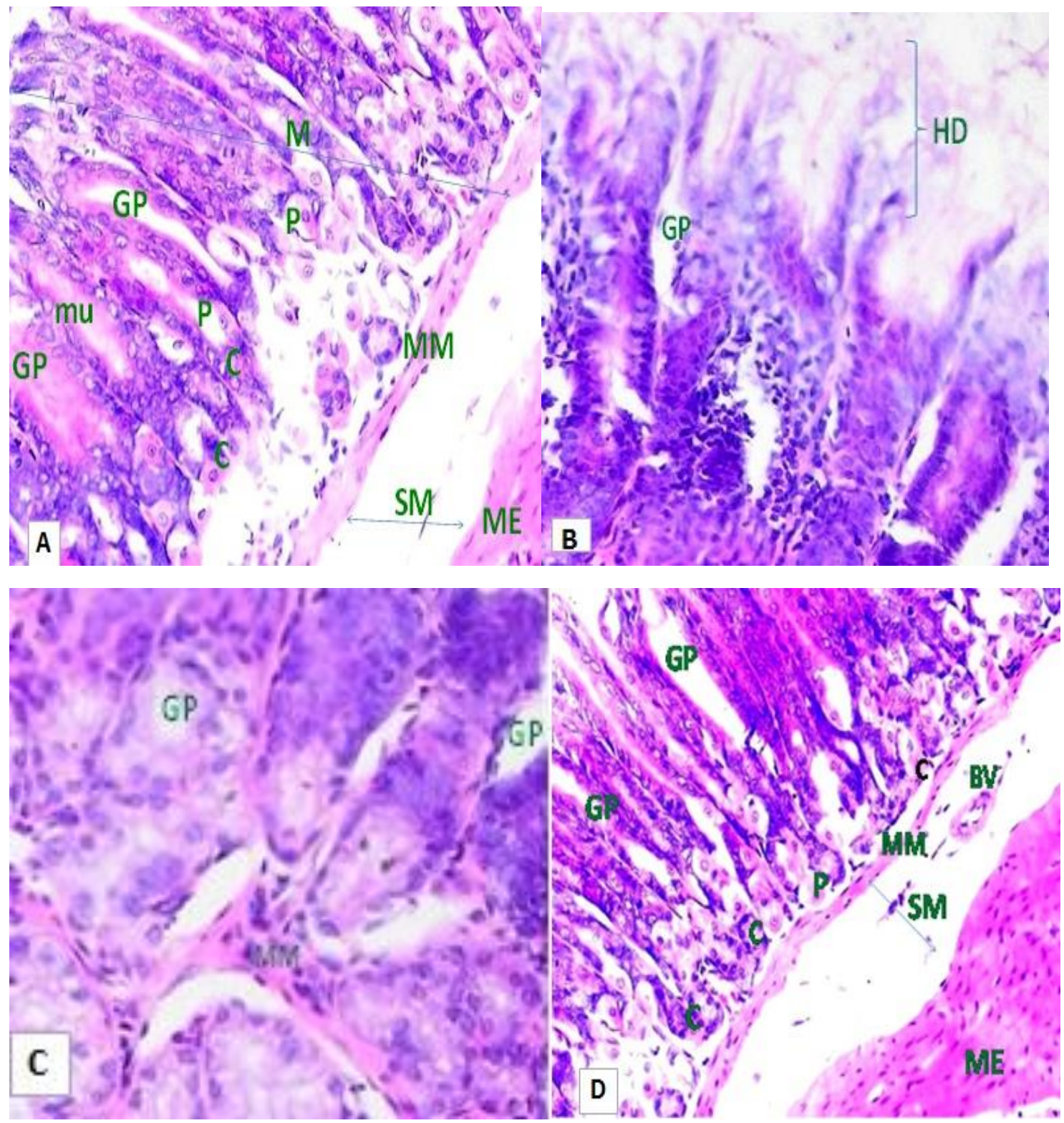

Figure 1: Photomicrographs of $H$ and E stained sections of stomach of mice treated with the aqueous root extract of G. stenophylla Gilg with 400 $\mathrm{mg} / \mathrm{kg}(\boldsymbol{A})$ and $800 \mathrm{mg} / \mathrm{kg}(\boldsymbol{B}$ and $\boldsymbol{C})$ as compared to the control $(\boldsymbol{D})$. Note hydropic degeneration (HD) of mucosal cells in the superficial parts of the gastric mucosa in the mice treated with $800 \mathrm{mg} / \mathrm{kg}$ body weight $(\boldsymbol{B})$. BV in $\boldsymbol{D}=$ blood vessel, $\mathrm{mu}$ in $\boldsymbol{A}=$ mucus-secreting cells, GP in all $=$ gastric pit, $\boldsymbol{P}$ in $\boldsymbol{A} \& \boldsymbol{D}=$ parietal cell, $\boldsymbol{C}$ in $\boldsymbol{A} \& \boldsymbol{D}=$ chief cell, $M$ in $\boldsymbol{A}=$ mucosa, $M M$ in $\boldsymbol{A}, \boldsymbol{C} \& \boldsymbol{D}=$ muscularis mucosae, $S M$ in $\boldsymbol{A} \& \boldsymbol{D}=$ submucosa, $M E$ in $\boldsymbol{A} \&$ $D=$ muscularis externa. Magnifications, all $=$ X 2100).

DOI: http://dx.doi.org/10.4314/ejhs.v27i1.6 
Light microscopic evaluation of the duodenal sections also showed that there was no significant difference between the mice treated with the oral doses of 400 (Figure 2a) and $800 \mathrm{mg} / \mathrm{kg}$ (Figure $2 \mathrm{~b}$ and $\mathrm{c}$ ) compared to that of the controls (Figure $2 \mathrm{~d})$. In all groups, the duodenal mucosa is intact and has the usual normal appearance with the characteristic villous mucosal form, and glandular crypts (crypts of Lieberkühn) between the roots of elongated villi extending down to the muscularis mucosae. The lamina propria forming the core of each villus also appeared normal. Moreover, the submucosa appeared normal, hosting an extensive mass of coiled branched tubular glands (Brunner's glands) (Figure 2a and $\mathrm{b}$ ). In the mice treated with $800 \mathrm{mg} / \mathrm{kg}$ (Figure 2b and c), however, cytoplasmic vacuolation, hydropic degeneration and desquamation of surface cells were evident compared to that of the controls.
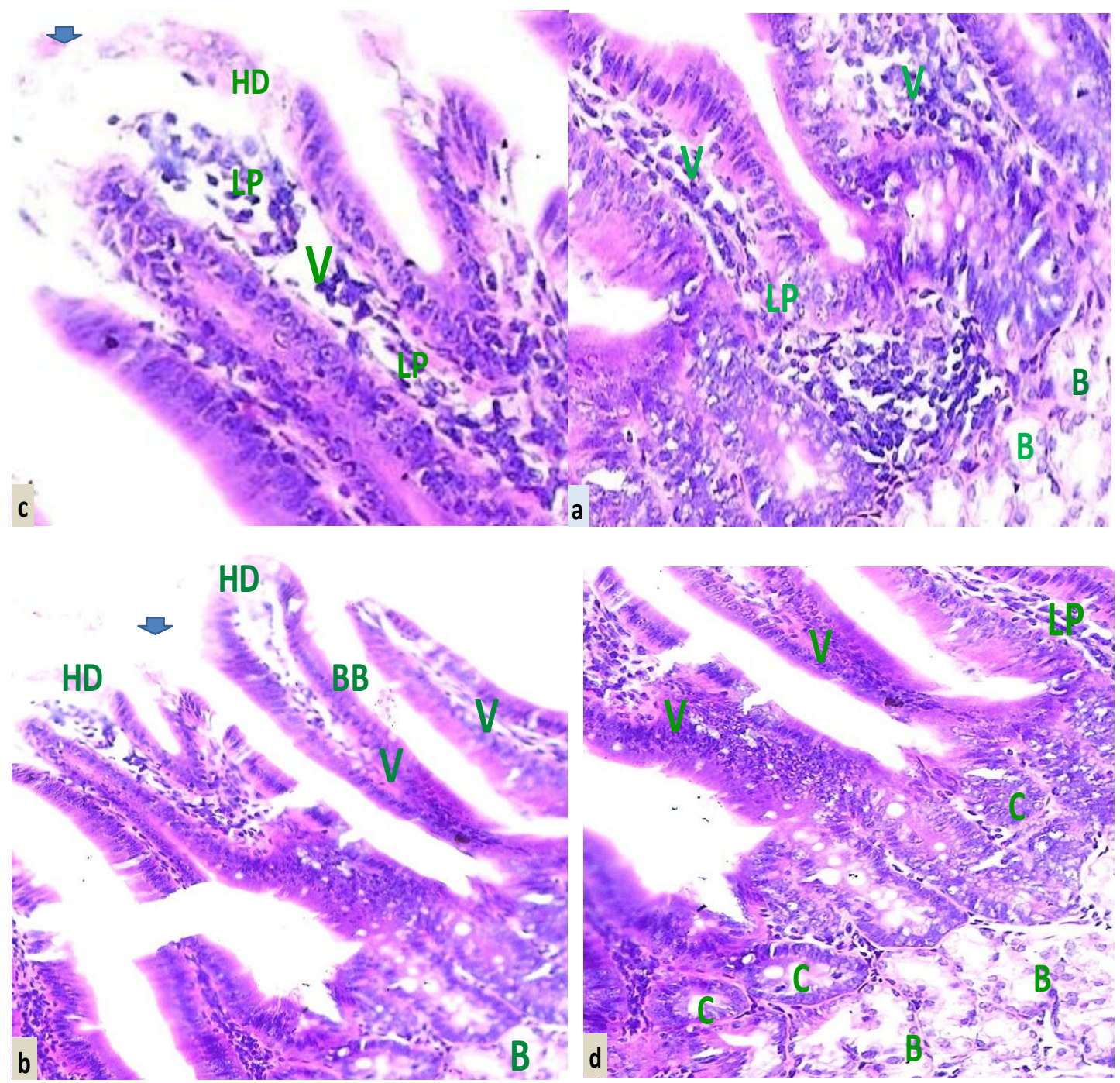

Figure 2: Photomicrographs of $H$ and $E$ stained sections of duodenum of mice treated with the aqueous root extract of G. stenophylla Gilg with 400 $\mathrm{mg} / \mathrm{kg}(\boldsymbol{a})$ and $800 \mathrm{mg} / \mathrm{kg}(\boldsymbol{b}$ and $\boldsymbol{c}$ ) as compared to the control $(\boldsymbol{d})$. Note hydropic degeneration (HD) and desquamation (arrow head) of mucosal cells at the tip of intestinal villi in the mice treated with $800 \mathrm{mg} / \mathrm{kg}$ body weight (b and $\boldsymbol{c}$ ). B in $\boldsymbol{a}, \boldsymbol{b} \& \boldsymbol{d}=$ Brunner's gland, BB in $\boldsymbol{b}=$ brush border, $C$ in $\boldsymbol{d}=$ crypts, $L P$ in $\boldsymbol{a}, \boldsymbol{c} \& \boldsymbol{d}=$ lamina propria, $V$ in all= villus. Magnifications, all = X 2100.

The effect of 13 weeks chronic oral treatment with the extract on histopathology of jejunum is shown in Figure 3. The jejunal sections of the mice treated with $400 \mathrm{mg} / \mathrm{kg}$ (Figure $3 \mathrm{a}$ and $\mathrm{b}$ ) appeared normal compared to those of the controls (Figure $3 \mathrm{e}$ and $\mathrm{f}$ ). The villi are lined by tall simple

DOI: http://dx.doi.org/10.4314/ejhs.v27i1.6 
columnar epithelium which is continuous with that of the crypts. The enterocytes, the predominant cell types, are taller columnar cells with basally located nuclei and distinct brush border at the luminal surface. Mucus-secreting goblet cells are also scattered among the enterocytes. A third type, Paneth cells found singly or in smaller clusters at the base of the crypts, are characterized by strongly eosinophilic granules (Figure 3e). The lamina propria extends between the crypts and
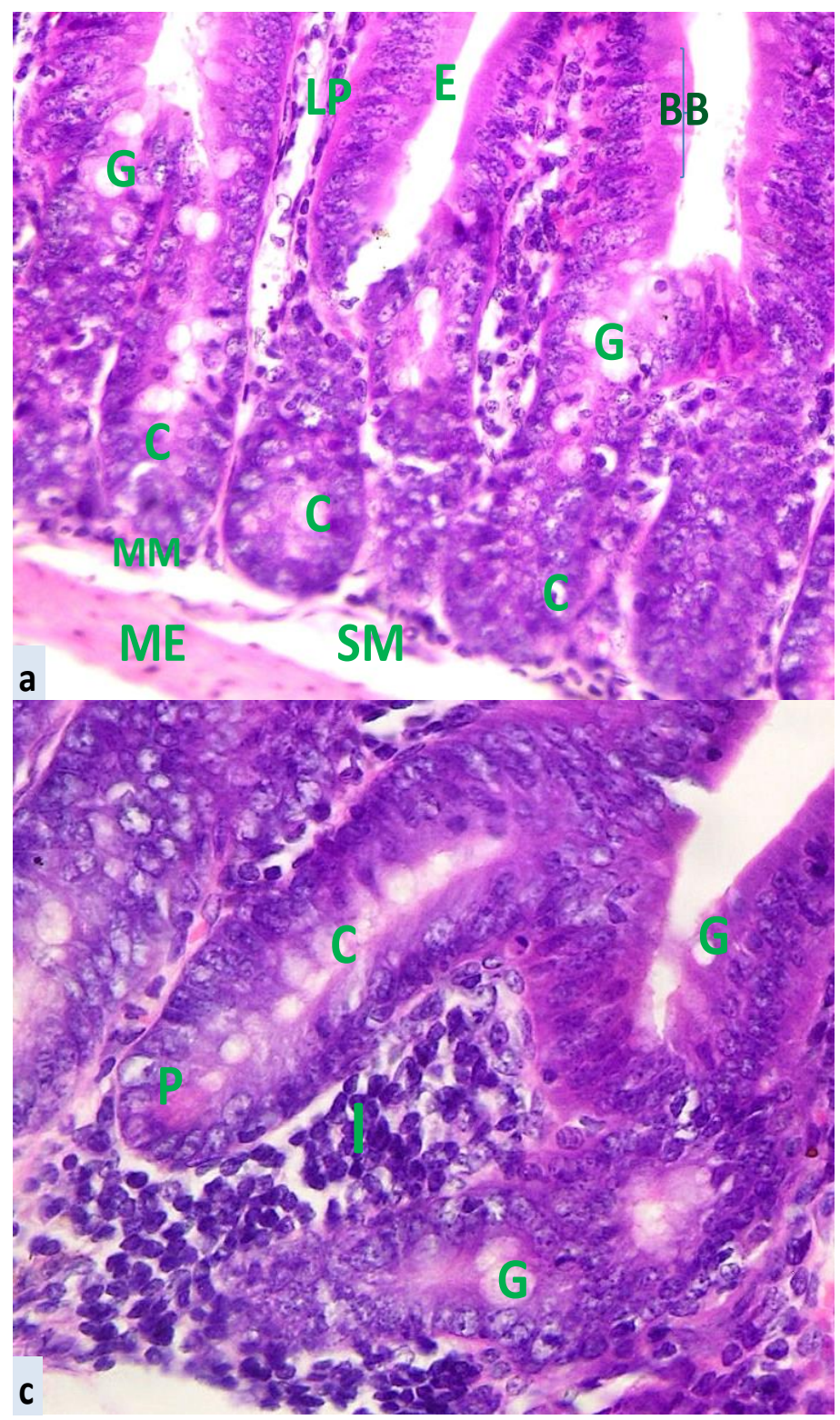

into the core of each villus, while the muscularis mucosa lies immediately beneath the base of the crypts (Figure 3a and b).

Sections of jejunum of the mice treated with $800 \mathrm{mg} / \mathrm{kg}$ showed slight inflammatory cell infiltration (I) at the root of some intestinal villi (Figure 3c), cytoplasmic vacuolation and hydropic degeneration. Excessive desquamation of surface cells is also evident at the tip of most of the intestinal villi (Figure 3d).
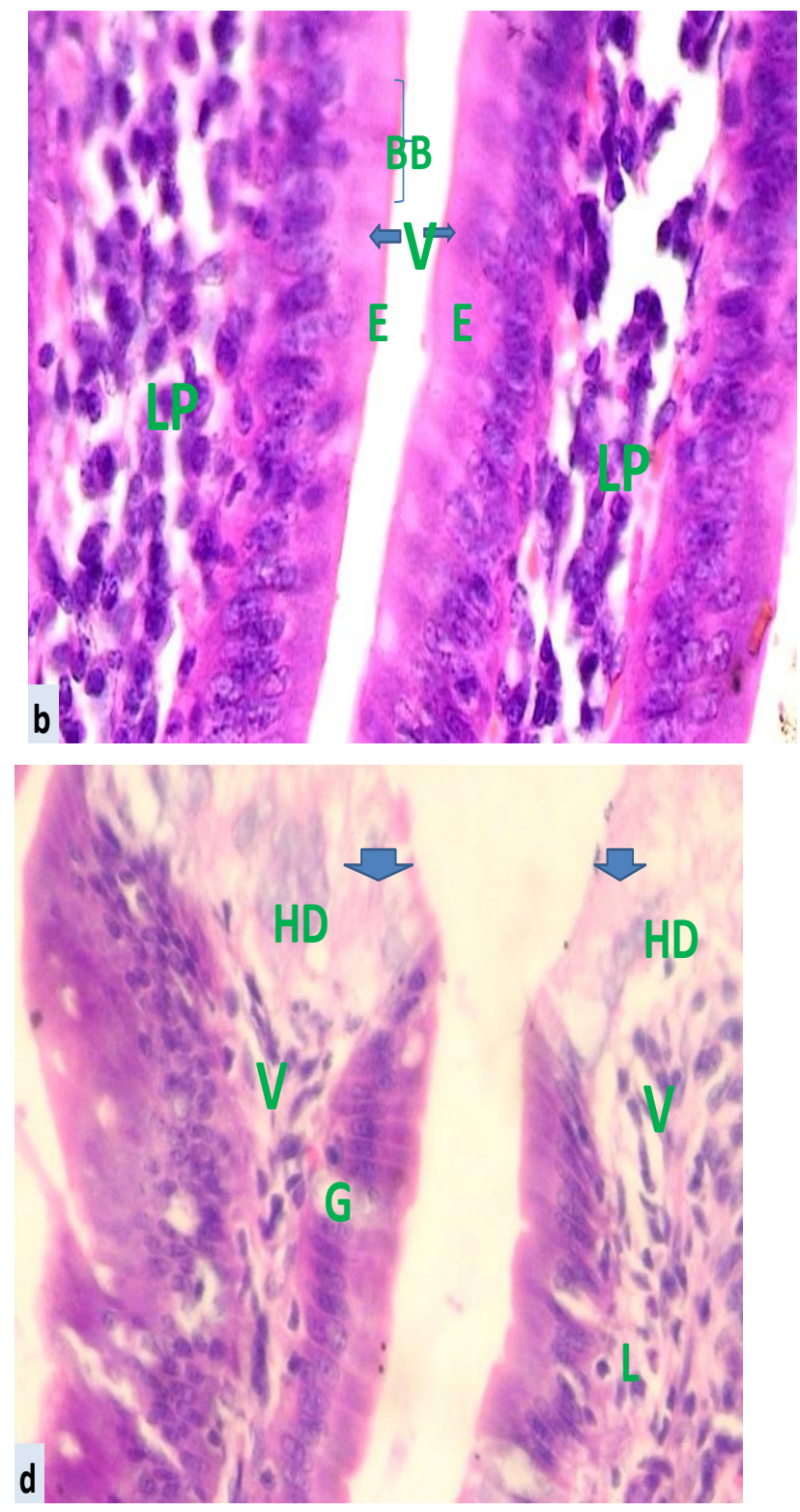

DOI: http://dx.doi.org/10.4314/ejhs.v27i1.6 

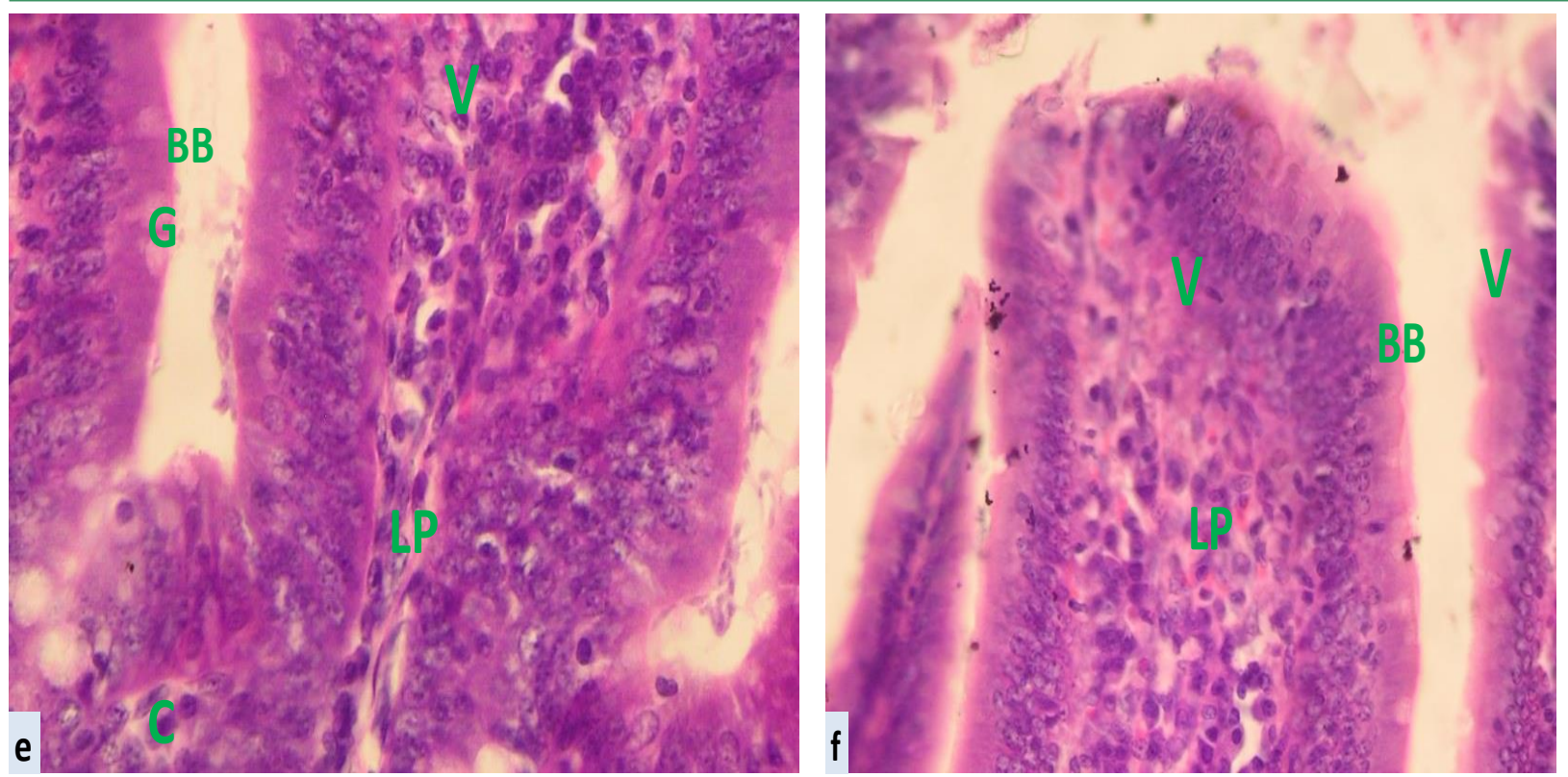

Figure 3: Photomicrographs of $H$ and E stained sections of jejunum of mice treated with the aqueous root extract of G. stenophylla Gilg with $400 \mathrm{mg} / \mathrm{kg}(\boldsymbol{a}$ and $\boldsymbol{b})$ and $800 \mathrm{mg} / \mathrm{kg}(\boldsymbol{c}$ and $\boldsymbol{d})$ as compared to that of the controls (e and $\boldsymbol{f}$ ). Note inflammatory cell infiltration (I) at the root of some intestinal villi as well as hydropic degeneration (HD) and desquamation (arrow head) of cells from the tip of the villi in the mice treated with $800 \mathrm{mg} / \mathrm{kg}$ body weight (c and $\boldsymbol{d}$ ). BB in $\boldsymbol{a}, \boldsymbol{b}, \boldsymbol{e} \& \boldsymbol{f}=$ brush border, $\boldsymbol{C}$ in $\boldsymbol{a}, \boldsymbol{c} \& \boldsymbol{e}=$ crypts, $\boldsymbol{E}$ in $\boldsymbol{a} \& \boldsymbol{b}=$ epithelium, $G$ in $\boldsymbol{a}, \boldsymbol{c}, \boldsymbol{d} \boldsymbol{\&} \boldsymbol{e}=$ goblet cells, I in $\boldsymbol{C}=$ infiltration, $L$ in $\boldsymbol{D}=$ lymphocyte, LP in $\boldsymbol{a}, \boldsymbol{b}, \boldsymbol{e} \& \boldsymbol{f}=$ lamina propria, $M M$ in $\boldsymbol{a}=$ muscularis mucosae, $M E$ in $\boldsymbol{a}=$ muscularis externa, $S M$ in $\boldsymbol{a}=$ submucosa, $\boldsymbol{P}$ in $\boldsymbol{c}=P$ aneth cell, $\boldsymbol{V}$ in $\boldsymbol{b}, \boldsymbol{d}, \boldsymbol{e} \& \boldsymbol{f}=$ villus. Magnifications, all= X2100.

\section{DISCUSSION}

The results of the 13 weeks oral administration of G. stenophylla in this study indicated that the extract was well tolerated by all animals. No animal was found dead until the scheduled 13 weeks of dosing. The body weight of both the treated and untreated animals of either sex increased progressively as the duration increased. Throughout the study period, extract treatment did not affect food intake of the mice at both doses. The significant increase in the food intake and body weights observed during the second, fourth, sixth, eighth and tenth weeks in the male mice treated with $800 \mathrm{mg} / \mathrm{kg}$ may suggest the nutritional value of the plant extract at the tested doses.

The gastrointestinal tract (GIT) is the first organ that directly comes in contact with orally introduced substances. Thus, potentially toxic substances taken through the oral route may damage GIT. In this study, gross morphologic examinations of the stomach, small intestine and large intestine of control and extract treated animals did not reveal any sign of lesion.
Moreover, microscopic evaluations of histological sections of GIT of the mice treated with $400 \mathrm{mg} / \mathrm{kg}$ did not reveal any appreciable histopathological alteration. In the mice treated with $800 \mathrm{mg} / \mathrm{kg}$, however, the gastric, duodenum and jejunal mucosae showed some cytoplasmic vacuolation and hydropic degeneration and excessive desquamation of surface cells. In addition, activation of inflammatory cells infiltration into the lamina propria and the lining epithelia are also evident. This correlates with one of the histopathological manifestations of gastrointestinal irritation (enteritis) that is related to a harmful metabolic activity as described by other investigators (33). The observed effect of the extract with $800 \mathrm{mg} / \mathrm{kg}$ body weight on the GIT in this study is similar with the findings of Diwan et al (33) who reported local irritation of GIT following oral treatment with saponin in mice. Likewise, Kiptoon et al. (26) reported irritation of the stomach mucosa in calves fed $G$. latifolia. Cytoplasmic vacuolation and hydropic 
degeneration seen in this study may occur as a result of retention of water inside the cells due to a reduction of energy necessary for ion regulation in the cells (32-33). Because of their action as a detergent, saponins are poorly absorbed, concentrate in lipid layer of the cell membranes and interfere with the process of ion transport across membranes (34). This may partly explain the vacuolar changes and hydropic degenerations of the digestive mucosa observed in this investigation as G. stenophylla root extract is known to contain saponins as bioactive ingredients (24).

In conclusion, the results of this study showed that the aqueous extract of $G$. stenophylla at an effective antimalarial dose $(400 \mathrm{mg} / \mathrm{kg}$ body weight) has no serious adverse effect on food intake and gross and histopathological appearance of GIT in mice. At a higher dose of $800 \mathrm{mg} / \mathrm{kg}$, however, the extract may induce gastrointestinal irritation. Therefore, further investigation on other vital organs and nonrodent species, including human, is recommended as mild enteritis is observed upon prolonged herbal administration. Nevertheless, absence of any morbidity at a therapeutic dose of $400 \mathrm{mg} / \mathrm{kg}$ body weight appears to support the general safety of $G$. stenophylla root extract as a herbal remedy for the treatment of malaria and may contribute to the development of new antimalarial drug from the species.

\section{REFERENCES}

1. Pankhurst R. An historical examination of traditional Ethiopian medicine and surgery. Ethiop Med J, 1965; 3 (4): 157-72.

2. Addis G, Abebe D, Genebo T, Urga, K. Perceptions and practices of modern and traditional health practitioners about traditional medicine in Shirka District, Arsi Zone, Ethiopia. Ethiop J Health Dev, 2002; 16 (1): 19-29.

3. Berhanu A. Book Review: Ethiopian traditional medicine: Common medicinal plants in perspective. $J$ Black Studies, 2002; 32: 610-612.
4. Gedif $\mathrm{T}$ and Hahn HJ. The use of medicinal plants in self-care in rural central Ethiopia. J Ethnopharmacol, 2003; 87: 155-161.

5. Peter A and De Smet GM. Traditional pharmacology and medicine in Africa: Ethnopharmacological themes in SubSaharan art objects and utensils. $J$ Ethnopharmacol, 1998; 63:171-175.

6. Azaizeh H, Saad B, Khalil K, Said O. Book Review: The state of traditional Arab herbal medicine in the Eastern region of the Mediterranean. Evidence-based Comp Alt Med, 2006; 3:229-235.

7. Alves R and Rosa I (2007). Biodiversity, traditional medicine and public health: Where do they meet? $J$ Ethnobiol Ethinomed, 2007; 3:1-14.

8. Pelletier RK. "Guide to Herbal Medicine", Electronic Database on DVD-ROM. Electronics Publishing Division, London, UK 2006.

9. Gedif T and Hahn HJ. Herbalists in Addis Ababa and Butajira, Central Ethiopia: Mode of service delivery and traditional pharmaceutical practice. Ethiop $J$ Health Dev, 2002; 16 (2):191-197.

10. Fassil H. Beyond plants, professionals \& parchments: The role of home-based medicinal plants use and traditional health knowledge in primary healthcare in Ethiopia. Ethnobotany Res \& App, 2005; 3: 37-49.

11. Kamuhabwa A, Nshimo C, de Write P. Cytotoxicity of some medicinal plant extracts Used in Tanzanian traditional medicine. J Ethnopharmacol, 2000; 70 (2): 143-149.

12. Chang LW, Dudley AW, Lee YK, Karz J. Ultrastructural changes in the kidney following chronic exposure to low levels of halothane. Amer J Patholo, 1975; 78 (2): 225-242.

13. Steenkamp V and Gouws M. Cytotoxicity of six African medicinal plant extracts used in the treatment of cancer. South African J Botany, 2006; 72: 630-633.

14. Peterson B. Thymelaeaceae. In: Flora of Ethiopia and Eritrea, Eds. Edwards S,

DOI: http://dx.doi.org/10.4314/ejhs.v27i1.6 
Tadesse M, Demissew S, Hedberg editors. Flora of Ethiopia and Eritrea, vol. 2; 1978; p. 429-431.

15. Edwards S, Tadesse M, Demissew S, Hedberg I. Flora of Ethiopia and Eritrea, Vol. 2, part I, 2000, Addis Ababa, Ethiopia; Uppsala, Sweden p. 429-450.

16. Chapman and Hall. Dictionary of Natural Products on CD-ROM. Chemicals Database. Version 5 (1) Electronics Publishing Division, London, UK, 1977.

17. Annon A. Dictionary of Natural Products on CD-ROM. Chapman and Hall Chemical Database. Electronics Publishing Division, London, UK, 1997.

18. Ashenafi A, Kelbessa U, Mulugeta G, Walelegn M, Daniel M, Kisie $M$ and Tesgaye K. In-vivo anti-malaria activity of plants used in Ethiopian traditional medicine, Delomenna southeast Ethiopia. Ethiop J Health Sci, 2007; 17:81-89.

19. Abebe D, Debella A, Urga K. Medicinal plants and other useful plants of Ethiopia. Nairobi: Compriex Publishers International; 2003. p. 43-57.

20. Ssegawa $S$ and Kasenene J. Plants for malaria treatment in Southern Uganda: Traditional use, preference and ecological viability. J Ethnobiol, 2007; 27 (1): 110.

21. Clarkson C, Vinesh JM, Nail C, Olwen G, Pamisha P, Motlaepula M, Niresh B, Peter F. In-vitro anti-plasmodial activity of medicinal plants native to or naturalized in South Africa. J Ethnopharmacol, 2004; 92: 177-191.

22. Kalauni S, Awali S, Tezuka Y, Banskota A, Linn T, Asih PB, Syafruuddin D, Kadota S. Antimalarial activity of Cassaneand norcassane-type diterpenes from Caesalpinia crista and their structureactivity relationship. Biol Pharm Bull, 2006; 29 (5): 1050-1052.

23. Ferrari J, Terreaux C, Sahpaz S, Msonthi JD, Wolfender JL, Hostettman K. Benzophenone glycosides from Gnidia involucrata. Phytochemistry, 2000; 54 (8): 883-9.

24. Mohammed M, Bisrat D, Debella A, Birhanu T. Standardization of the Roots of
Gnidia stenophylla Gilg: A Potential Medicinal Plant of South Eastern Ethiopia Traditionally Used as an Antimalarial. International Science Index, 2014; 1(11), waset.org/abstracts/7458.

25. Abebe D, Urga K, Debella A, Ambaye C, Dejene A. Survey of poisonous plants in Southern Ethiopia. Ethiop J Health Dev, 2001; 15 (3): 209-221.

26. Kiptoon JC, Mugera GM, Waiyaki PG. Hematological and biochemical changes in cattle poisoned by Gnidia latifolia syn. Lasiosiphon latifolia (Thymelaeaceae). Toxicology, 1982; 25 (2-3): 129-39.

27. Mebratu A, Yamrot K, Eyasu M, Yonas B, Kelbessa U, Mekbeb A. Toxicological evaluation of methanol leaves extract of Vernonia bipontini Vatke in blood, liver and kidney tissues of mice. African Health Sci, 2014; 14 (4): 1012-1024.

28. Hayelom K, Mekbeb A, Eyasu M, Wondwossen E, Kelbesa U. Toxicological investigation of chronic treatment with Clerodendrum myricoides on blood, liver and kidney tissues of mice. African Health Sci, 2012; (4): 489 - 497.

29. Pieme C, Penlap V, Nkeæ B, Taziebou C, Tekwu E, Etoa F, Ngongang J. Evaluation of acute and subacute toxicities of aqueous and ethanolic extracts of leaves of Senna alata (L.) Roxb (Ceasalipiniaceae). African J Biotechnol, 2006; 5: 283-289.

30. WHO. General guidelines for methodologies on research and evaluation of traditional medicine. WHO/EDM/TRM/2000.1.

31. Kilkenny C, Browne WJ, Cuthill IC, Emerson M, Altman DG. Improving bioscience research reporting: The ARRIVE Guidelines for Reporting Animal Research. PLOS Biol, 2010; 8 (6): e1000412, doi: 10.1371/journal.pbio.1000412.

32. Nwinyi FC, Binda L, Ajoku GA, Aniagu SO, Enwerem NM, Orisadipe A, Kubarawa D, Gamaniel KS). Evaluation of the aqueous extract of Boswellia dalzielii stem bark for antimicrobial activities and 
gastrointestinal effects. African $J$ Biotechnol, 2004; 3 (5): 284-288.

33. Diwan FH, Abdel-Hassan IA, Mohammed ST. Effect of saponin on mortality and histopathological changes in mice. Eastern Mediterranean Health J, 2000; 6: 345-351.
34. Opta MM and Izevbigie EB. Aqueous Vernonia amygdalina extracts alter MCF-7 cell membrane permeability and efflux. International J Env Res and Public Health, 2006; 3 (2): 174-179 